UDC 332: 361

\title{
PECULIARITIES OF GEODESIC WORKS WITH THE USE OF UAVS FOR THE NEEDS OF LAND MANAGEMENT
}

Butenko E.V., Candidate of Economic Sciences

Email:evg_cat@ukr.net

National University of Life and Environmental Sciences of Ukraine

Nevoit N.O.,student

Email: nevoyt.nata@gmail.com

National University of Life and Environmental Sciences of Ukraine

It is determined and substantiated that the most popular type of survey activity for land management is the use of unmanned aerial vehicles, as most traditional methods of geodetic surveys are not effective enough today, they can not provide the required measurement accuracy, especially for landowners and land users. , is very important. An approximate algorithm for the use of unmanned aerial vehicles to solve geodetic problems of land management of united territorial communities, which includes stages of preparation from re-survey to create a digital terrain model, the advantages of using unmanned aerial vehicles over traditional types of geodetic surveys. analyzed a number of features of the use of unmanned aerial vehicles in geodetic surveying for the needs of OTG land management, calculated the economic efficiency of this type of geodetic surveys on a specific example, namely the village of Gamaliyivka Pustomyty district of Lviv region and compared the comparison of traditional costs and time training and the use of unmanned aerial vehicles. At the same time, the ways of improving the process of aerial photography with the help of UAVs are presented both at the normative and at the organizational and technical level. namely, the settlement of Gamaliyivka, Pustomyty district, Lviv region, and a comparison of the cost of time and money in comparison with the traditional method of geodetic surveys and the use of unmanned aerial vehicles. At the same time, the ways of improving the process of aerial photography with the help of UAVs are presented both at the normative and at the organizational and technical level. namely, the settlement of Gamaliyivka, Pustomyty district, Lviv region, and a comparison of the cost of time and money in 
comparison with the traditional method of geodetic surveys and the use of unmanned aerial vehicles. At the same time, the ways of improving the process of aerial photography with the help of UAVs are presented both at the normative and at the organizational and technical level.

Keywords: unmanned aerial vehicles, geodetic surveys, aerial photography, land management works, planned-vistona basis, economic efficiency, orthophotoplan

Formulation of the problem.Drastic changes in priorities and strategic guidelines in the system of domestic land use, which are taking place in recent years and aimed at removing land resources from the shadows, correcting errors and shortcomings in the cadastral accounting system OTG, improving the accuracy and reliability of cadastral information on land, cause turn and the need to transform the methods and techniques of land management. It is clear that most traditional methods and technologies of geodetic surveying for land management needs today are not efficient and sufficient, as they require a lot of effort, time and considerable resources. In addition, they cannot fully ensure the required measurement accuracy, which is very important, especially for owners and users of small plots of land.

Therefore, in recent years there is a need to develop and test fundamentally new forms and methods of geodetic works for land management, primarily based on aerial photography and satellite imagery. However, satellite imagery, giving the highest level of accuracy and reliability of the data of site boundaries and the structure of their terrain, is extremely expensive and problematic, as it requires a combination of many conditions and factors - quality software, reliable communication, location of satellites. etc. And aerial photography from airplanes and helicopters, giving a good result with lower requirements, is still too expensive and not very suitable for small land areas [6, p. 433].

In such conditions, the use of unmanned aerial vehicles for land management, namely for geodetic works to prepare orthophotos with their subsequent digitization and development on their basis plans for different needs (for construction, clarification of site boundaries, change of owners, cadastral changes etc.) is today the most popular type of exploration for land management. Therefore, the study of the use of unmanned 
aerial vehicles in geodetic surveying for land management is extremely important, significant and relevant.

The aim of the study.Investigate the features of geodetic works with the use of UAVs for land management.

Results of research and discussion.As land management works occupy an important place in the system of land relations of Ukraine and aim to create a complete package of land management documentation, which includes regulatory, technical, economic and evaluation documents for certain actions with land (granting, transfer, alienation, redemption), division, unification of lands), then, accordingly, the conduct of geodetic surveys is now given considerable attention.

In recent years, the most effective way of accurate, reliable and cost-effective geodetic measurement of OTG lands has been aerial photography using UAVs unmanned aerial vehicles that can perform tasks in the air without a pilot with different control and communication systems [4, p. . 82]. Unmanned aerial vehicles can be used in many areas of public relations, especially in military and military intelligence, but their role in land management is difficult to overestimate today. In addition, aerial photography with UAVs has a number of advantages over traditional types of geodetic surveys - UAVs are very mobile, have great economic benefits, extremely accurate, safe for humans and the environment, and can be used anywhere and in any weather..

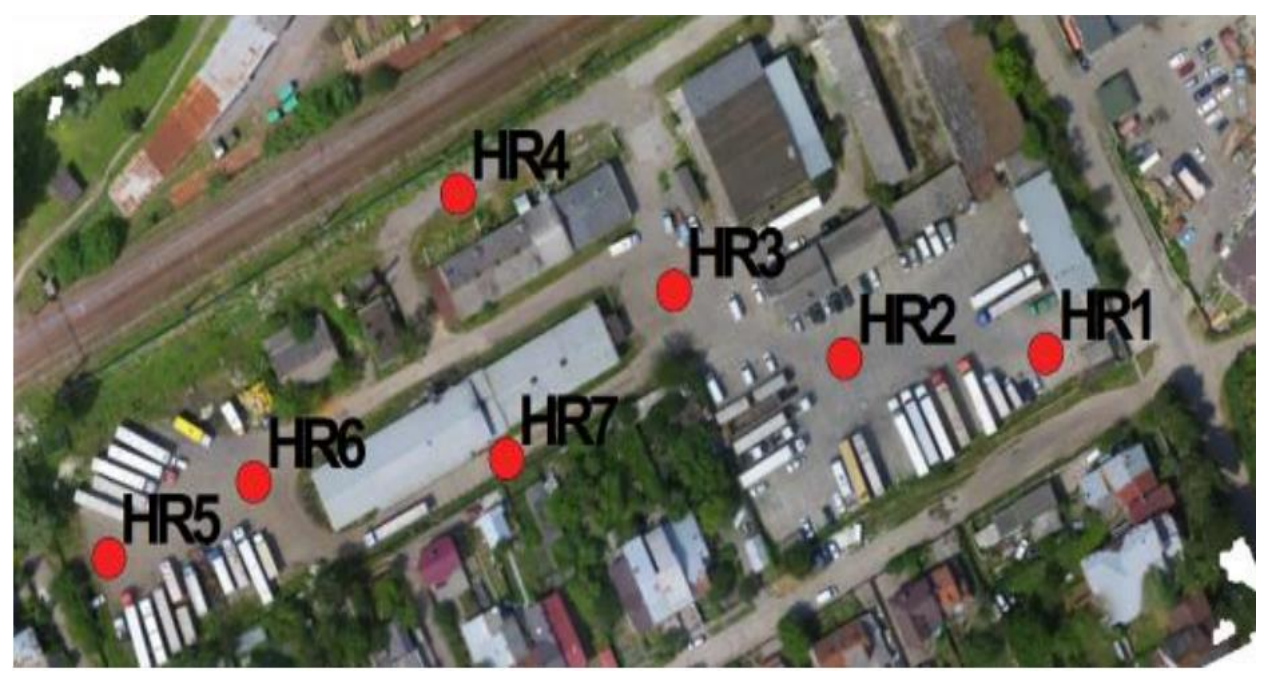

Fig. 1.A fragment of an orthophotoplan of the area with a planned height altitude (at checkpoints) of the settlement of Gamaliyivka, Pustomyty district, 
The approximate algorithm for the use of unmanned aerial vehicles to solve geodetic problems of land management OTG lands is as follows:

1) conducting preliminary training (setting tasks, delineating the UAV route, entering flight data, etc.);

2) aerial photography of the land plot;

3) transmission of GPS surveillance data to a processor or computer;

4) synchronization of raw obtained images of the area with the accumulated GPSdata;

5) correction of data distortions and errors during synchronization;

6) generation of points and their further group alignment;

7) generation of 3-D-point terrain model (or DEM - digital terrain model) [3, p. $65]$.

However, well-known domestic scientists, in particular V. Glotov, Y. Gubar, V. Galetsky and others. clarify and specify this algorithm, highlighting, in particular, the stage of marking reference and control points for the implementation of discharged plan-height binding of the territory (area), as well as the creation of orthophotoplan, which is based on software identification of pixels in adjacent images. in turn, not only automatic triangulation, but also automatic search for characteristic points in the visible image (usually several hundred), stitching of individual blocks with their subsequent external and internal orientation, as well as creating a cloud of points on the earth's surface (Fig. 2) [2-4] .

Researchers also note that conducting geodetic surveying works for the needs of OTG land management with the use of UAVs has a number of special conditions and requirements, in particular:

1. The UAV can operate in an extremely wide weather range, but the best weather for its operation is quiet, windless and clear, the temperature is moderate. When the wind increases, the calibration and glide path of the UAV require very fine tuning.

2. Under optimal conditions of aerial photography, the UAV can shoot up to 8 square meters during the day. $\mathrm{km}$. territory (this, of course, depends on the model of the UAV, the quality and speed of the software, the purpose of the survey, etc.). 
3. It usually takes 5 to 15 minutes to prepare a UAV for flight, depending on the type, modification of the device and the cameras installed on it.

4. The optimal height of aerial photography with the help of UAVs is $100-300 \mathrm{~m}$. This achieves extremely high accuracy in determining the spatial and ground coordinates - up to $2 \mathrm{~cm}$ on the ground and up to $4 \mathrm{~cm}$ in space.

5. The project of execution of the planned works is controlled and managed automatically (sometimes - by means of the control panel). Thus on processing of 1 sq.m. km of UAV territory takes an average of 1.5-2 hours.

6. The quality of materials obtained during the work is assessed immediately after the end of the UAV [4, p. 133].

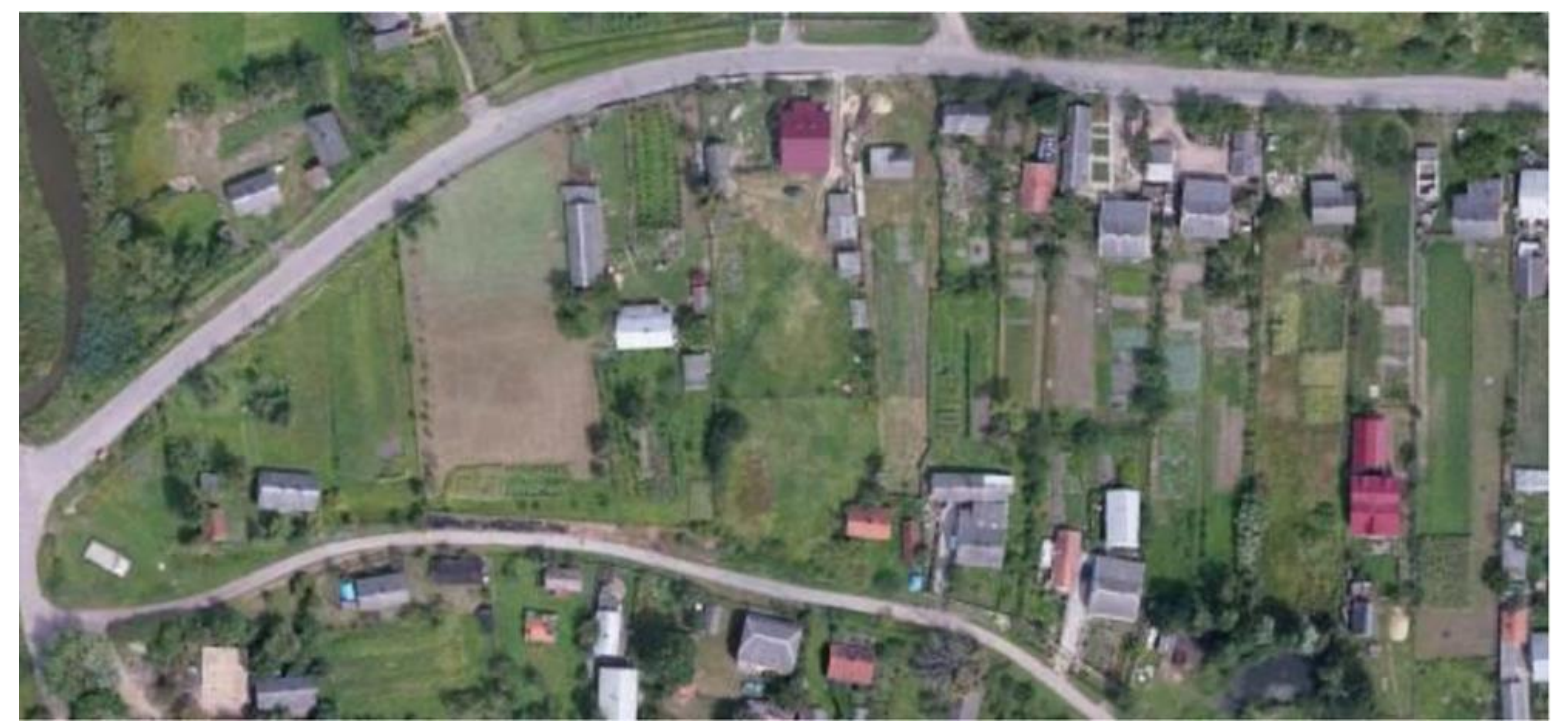

Fig. 2.A fragment of an orthophotoplan of the settlement of Hamaliyivka, Pustomyty district, Lviv region

Practical approbation geodetic surveys in the field with the use of UAVs also showed the high economic efficiency of this method of measurement for land management.

Thus, in the process of conducting geodetic works on the land plot (for allocation of land plots for construction) in the residential rural area, a comparison of time and money costs was carried out in two cases - using traditional assessment methods and using UAVs (Table 1). 
Table 1

Calculation of time spent on land management works using traditional assessment methods and UAVs

\begin{tabular}{|c|c|c|c|c|c|c|c|c|c|}
\hline \multirow{2}{*}{$\begin{array}{c}\text { № } \\
\text { s / } \\
\text { n }\end{array}$} & Types of & \multicolumn{2}{|c|}{$\begin{array}{c}\text { Time spent on the } \\
\text { object, hours }\end{array}$} & \multicolumn{2}{c|}{$\begin{array}{c}\text { Time spent on 1 } \\
\text { ha of territory, }\end{array}$} & \multicolumn{2}{|c|}{$\begin{array}{r}\text { The total number } \\
\text { of objects }\end{array}$} & \multicolumn{2}{|c|}{$\begin{array}{c}\text { Total time spent, } \\
\text { hours }\end{array}$} \\
\cline { 3 - 10 } & & UAV & $\begin{array}{c}\text { Traditions. } \\
\text { methods }\end{array}$ & UAV & $\begin{array}{c}\text { Traditions. } \\
\text { methods }\end{array}$ & UAV & $\begin{array}{c}\text { Traditions. } \\
\text { methods }\end{array}$ & UAV & $\begin{array}{c}\text { Traditions. } \\
\text { methods }\end{array}$ \\
\hline 1 & Preparatory & 0.10 & 0.10 & 1 & 1 & 100 & 100 & 10 & 10 \\
\hline 2 & Field & 0.10 & 0.20 & 1 & 2 & 100 & 100 & 10 & 20 \\
\hline 3 & In-house & 0.05 & 0.05 & 0.5 & 0.5 & 100 & 100 & 5 & 5 \\
\hline 4 & Total & 0.25 & 0.35 & 2.5 & 3.5 & 100 & 100 & 21 & 35 \\
\hline
\end{tabular}

According to the information of the leading land management organizations, the average time spent on one land plot during preparatory works is 5-7 minutes, during field works - 10-15 minutes, during in-house works - 2-5 minutes. Based on these norms of time consumption, it is calculated that the total time consumption in traditional estimation methods for geodetic and measuring works is about 35 hours (of which about 20 hours - directly for field measurements). When carrying out direct photographic and measuring actions in the field with the use of UAVs, the time costs are actually halved - from 20 to 10 hours, which gives, respectively, significant savings and free time for the implementation of subsequent projects.

INon average, one hour of work of a professional land appraiser today is about UAH 500, for an hour of work of a surveyor, this amount of funds is on average UAH 550. Therefore, according to calculations, the economic benefit of this technique is almost $67 \%$ :

$$
\mathrm{E}=\left(\frac{\mathrm{V}_{\mathrm{t}}-\mathrm{V}_{\mathrm{h}}}{\mathrm{V}_{\mathrm{h}}} * 100 \%\right)
$$

where $\mathrm{E}$ is the overall efficiency of the introduction of new methods of geodetic works;

$\mathrm{Vt}$ - time spent on geodetic works by the traditional method;

Vh - time costs for geodetic works using UAVs [2, p. 88]. 
Thus, the effectiveness of the introduction of a new method of geodetic works with the introduction of UAVs will be:

$$
\begin{gathered}
E=\left(\frac{35-21}{21} * 100 \%\right) \\
E=66,7 \%
\end{gathered}
$$

At the same time, despite the constant increase in the share of UAVs in the process of geodetic and measuring works for land management, there are many ways to improve this process at both regulatory and organizational and technical levels. At the regulatory level, it is proposed to introduce a new special classification of UAVs for civilian needs, approximation of the domestic regulatory framework for the use of UAVs in economic activities to European standards, clarification of UAV identification, compilation of their unified state register, etc. At the technical level it is:

- active use of Lidar technology in combination with aerial photography with UAVs;

- overcoming the existing technical shortcomings and problems related to checkpoints, UAV synchronization in flight, setting up imaging equipment, etc .;

- active commissioning of the latest domestic unmanned systems for civilian needs, which are not inferior to the best foreign counterparts, and in some respects even surpass them, launch and landing systems;

- clarification and optimization of the block diagram of geodetic works (unification according to EU norms and regulations), etc. [3, p. 68]

Conclusions. he current state of land relations in Ukraine causes an urgent need for a variety of land management works aimed at finding and designing the organization of the territory. Land management is the initial, basic process of land management law and land relations, so the solution of important and relevant issues related to land management, its optimization and the search for new forms and methods of improvement is extremely important and relevant.

Thus, the use of unmanned aerial vehicles for geodetic works in land management is the most promising new method of land management, which gives many advantages 
over traditional methods of land management and opens wide opportunities for further geodetic and cartographic research.

\section{References}

1. Butenko E.V., Kulakovsky O.B. Zastosuvannya bezpilotnih litayuchih sistem pri virishenni zadach zemleustroyu [Application of unmanned flying systems in solving land management problems] Ukraine, Kyiv: NUBIP, 68-73

2. Galetsky V., Glotov V., Kolesnichenko V., Prokhorchuk O., Tserklevych A. (2012). Analiz eksperimentalnih robit zi stvorennya velikomasshtabnih planiv silskih naselenih punktiv pri zastosuvanni BPLA [Analysis of experimental work on the creation of large-scale plans of rural settlements with the use of UAVs] Ukraine, Kyiv: Science, 85-93.

3. Glotov V., Gunina A. (2014). Analiz mozhlivostej zastosuvannya bezpilotnih litalnih aparativ dlya aeroznimanih procesiv [Analysis of the possibilities of using unmanned aerial vehicles devices for aerial photography processes] Ukraine, Kyiv: Science, 65-70.

4. Gubar Y. (2017). Analiz docilnosti zastosuvannya bezpilotnih litalnih aparativ dlya masovoyi ocinki neruhomosti naselenih punktiv [Analysis of the feasibility of using unmanned aerial vehicles devices for mass real estate appraisal of settlements]. Proceedings of the II All-Ukrainian scientific conference "Geodesy, land management, geoinformatics in the Southern region: current status and development prospects", 131-135.

5. Rostopchin V.V. (2016) Unmanned aerial systems: basic concepts. ELECTRONICS: Science, Technology, Business №7, 82-88.

6. Tretyak A.M. (2014). Land management [Land management] Ukraine, Kherson: Oldplus, 520.

7. Meier G., Frank S. (2019) Dokumentation und Überwachung einer Rutschung mittels UAV (Unmanned Aerial Vehicle), Geodäsie/Vermessung, Geomatik Schweiz - 449-452.

8. Rinaudo F., Chiabrando F., Lingua A. M., Spanò A. T. (2020) Archaeological site monitoring: UAV photorammetry can be an answer. The International 
archives of the photogrammetry, Remote sensing and spatial information sciences, 39(B5) - 583-588

\section{Бутенко Є.В., Невойт Н.О.}

\section{ОСОБЛИВОСТІ ПРОВЕДЕННЯ ГЕОДЕЗИЧНИХ РОБІТ IЗ} ЗАСТОСУВАННЯМ БПЛА ДЛЯ ПОТРЕБ ЗЕМЛЕУСТРОЮ

Визначено та обтрунтовано, щуо найбільш затребуваним видом вишукувальної діяльності для землеустрою є застосування безпілотних літальних апаратів, так як більшість традиційних методів геодезичних вичукувань є на сьогодні не досить ефективними, вони не можуть забезпечувати необхідну точність вимірювань, щуо, особливо для землевласників та землекористувачів невеликих земельних ділянок, є дуже важливим. Наведено орієнтовний алгоритм застосування безпілотних літальних апаратів для вирішення геодезичних завдань землеустрою земель об'єднанних територіальних громад, щз включає в себе етапи робіт від підготовки аєрознімання до створення цүифрової моделі рельєфу, розглянуті переваги використання безпілотних літальних апаратів в порівнянні з традиційними видами геодезичних робіт, проаналізовано ряд особливостей використання безпілотних літальних апаратів при проведенні геодезично-вишукувальних робіт для потреб землеустрою ОТГ, розрахована економічна ефективність даного виду геодезичних вишукувань на конкретному прикладі, а саме населеного пункту Гамалї̈ка Пустомитівського району Львівської області та проведено порівняння затрат часу та коштів у порівнянні з традиційним методом геодезичних робіт та методу із застосуванням безпілотних літальних апаратів. Разом з тим, представлено шляхи удосконалення процесу аерознімання за допомогою БПЛА як на нормативному, так і на організаційно-технічному рівні.

Ключові слова: безпілотні літальні апарати, геодезичні вищукування, аерофотозйомка, землевпорядні роботи, планово-висотна основа, економічна ефективність, ортофотоплан 


\section{Бутенко Е.В., Невойт Н.А.}

\section{ОСОБЕННОСТИ ПРОВЕДЕНИЯ ГЕОДЕЗИЧЕСКИХ РАБОТ С}

ИСПОЛЬЗОВАНИЕМ БПЛА ДЛЯ НУЖД ЗЕМЛЕУСТРОЙСТВА

Определено и обосновано, что наиболее востребованным видом изыскательской деятельности для землеустройства является применение беспилотных летательных аппаратов, так как большинство традиционных методов геодезических изысканий является на сегодня недостаточно эффективными, они не могут предоставить требуемую точность измерений, что особенно важно для землевладельцев и землепользователей небольших земельных участков. Приведён ориентировочный алгоритм применения беспилотных летательных аппаратов для решения геодезических задач земель объединеных территориальных общин, включающий в себя этапь от подготовительных работ к созданию циирровой модели рельефа. Рассмотрены преимущества использования беспилотных летательных аппаратов в сравнении с традищионными видами геодезических работ, проанализирован ряд особенностей использования беспилотных летательных аппаратов при проведении геодезии для нужд землеустройства ОТГ, вычеслена экономическая эффективность данного вида геодезических изысканий на конкретном примере, а именно населенного пункта Гамалеевка Пустомытовского района Львовской области и проведено сравнение затрат времени и средств по сравнению с традициоными методами геодезических работ и с применением беспилотных летательных аппаратов. Вместе с тем, представлены пути овершенствования процесса аэросъемки с помощью БПЛА как на нормативном, так и на организачионно-техническом уровне.

Ключевые слова: беспилотные летательные аппараты, геодезические изыскания, аэрофотосъемка, землеустроительные работы, планово-высотная основа, экономическая эффективность, ортофотплан 
